\title{
Apology Strategies Employed by the Public Figures in the Open Letters of Chinese and English Shanshan Xu
}

\author{
Zhengzhou University of Science and Technology, No.1 Xueyuan Road, Erqi District, Zhengzhou, \\ Henan Province, China
}

xssxsd@163.com

Keywords: Speech act; Apology strategy; Intercultural pragmatics; Communication skill

\begin{abstract}
This study investigates the similarities and differences on apology strategies employed by the public figures based on the data analysis of some English and Chinese open letters and makes an explanation in the perspective of intercultural pragmatics to foster the communication skills.
\end{abstract}

\section{Introduction}

In recent years, an apology as a speech act has attract many scholars' attention. It should be noted that most of the research on apology focus on the context of daily life. However, public figures with social status have an important influence on the whole society. Their speech act, making open apologies through the mass media, should cause great concern. This study concentrates on the apology strategies under the circumstance of mass media (that is the open letters of English and Chinese) and explores the similarities and differences on the adoption of apology strategies between English and Chinese to facilitate a more accurate and comprehensive understanding of the apology speech act, which will, in turn, lead to more successful intercultural communication between people.

\section{Previous Research}

Apologies. An apology is defined as "a speech act which is intended to provide support for the hearer who was actually or potentially malaffected by a violation' [1]. When he/she agrees to offer an apology, the speaker expresses his/her willingness to humiliate himself/herself to an extent which, by definition, makes an apology a face-saving act for the hearer and a face threatening act for the speaker.

Apologies fall under expressive speech acts, where the speaker attempts to indicate his/her own state or attitude. In order for an apology to have an effect, it should reflect true feelings. A person cannot successfully apologize to another and truly reach him/her unless he or she expresses his or her ture feelings of sorrow and regret what he or she did for the offense. As Gooder and Jacobs [2] indicated, the proper and effective apology acknowledges the fact of wrong doing, takes primary responsibility, conveys sincere sorrow and regret, and promises not to offend the victim again. . . Some of the characteristics of the effective apology are the admission of offense, the implied acknowledgement of responsibility, an expression of regret, and make a promise that injury will not recur in the future.

Apology Strategies. The literature suggests that for an apology to be convincing, the offender always adopts one or more strategies to make an apology. Fraser [3], for example, put forward four direct apology strategies, that is stating one's obligation to apologize, announcing the apology, offering to apologize, and requesting acceptance and five indirect apology strategies that is requesting forgiveness, promising forbearance, expressing regret, acknowledging responsibility, and offering redress. Similarly, Olshtain [1] and Olshtain and Cohen [4]distinguished two general apology strategies, that is using an illocutionary force indicating device (IFID), expressing responsibility and three situation-specific apologies strategies, that is explanation, offer of repair, and promise of forbearance. Based on the predecessor's research, Holmes [5] proposed four main 
strategies, that is acknowledgement of responsibility, explicit expression of apology, explanations, and promise to restrain himself or herself to express apologies by her New Zealander respondents.

In a study of the frequency of native speakers of and Arab learners of English's use of apology strategies, Al-Hami [6] reported that expression of apology, explanation of reason, acknowledgement of responsibility, repair, promise to restrain himself or herself, and expressing true feeling of sorrow and concern for the hearer were employed. He further expatiated the use of three devices of apology intensification: intensifiers (e.g., very); repetition (e.g., I am sorry, sorry, sorry); and a combination of both (e.g., I am very very sorry).

In a similar study of the apology strategies used by native speakers and non-native speakers, A. Trosborg [7] deals with one particular communicative act, that is the act of apologizing, as realized in the speech of Danish learners of English compared to native speaker performance and this research had a profound impact on communicative behavior in terms of these strategies

The model. The model used in my study has been based on A. Trosborg [8] as well as features of apology in the open letter.

(1) Illocutionary force indicating devices [IFID]

a. An expression of regret, e.g. I'm sorry.

b. An offer of apology, e.g. I apologize.

c. A request for forgiveness, e.g. Excuse me; forgive me; Pardon me.

(2) Taking on responsibility

a. Explicit self-blame, e.g. It is my fault/my mistake.

b. Lack of intent, e.g. I didn't mean it.

c. Expression of self-deficiency, e.g. I was confused/l didn't see you/I forgot.

d. Expression of embarrassment, e.g. I feel awful about it.

e. Self-dispraise, e.g. I'm such a dimwit!

f. Justify hearer, e.g. you're right to be angry.

(3) Promise of forbearance, e.g. It won't happen again.

(4) Offer of repair, e.g. I'll pay for the damage.

(5) Statement of apology fact, e.g. There have been numerous reports about what I said in Cannes.

(6) Explanation or account, e.g. the traffic was terrible.

(7) Concern for the hearer, e.g. I hope I didn't upset you/Are you all right?

(8) Refusal to acknowledge guilt, e.g. It wasn't my fault.

(9) Expression of gratitude, e.g. We appreciate China's efforts to see to the well-being of our crew.

(10) Put forward to wish or demand, e.g. I hope this clarifies matters for you.

Speakers habitually resort to a limited number of verbal strategies. It is assumed that the choice and final linguistic realization of these strategies is context- and culture-sensitive, so there exist some features about apologies by the public figures in the popular media as well as some differences between western and eastern culture.

\section{The Data Collection and Analysis}

From the internet of Google (famous American search engine) and Baidu (famous Chinese search engine), 5 pieces of English apology letters and 5 pieces of Chinese apology letters were collected at random. All these letters were addressed by the public figures.

The strategies used by the western and eastern public figures were tabulated, which made it possible to determine the strategies used by each sample group and whether or not strategy use was affected by context and culture. 
Table 1 Numbers of the apology strategies used by the public figures in the open letters of Chinese.

\begin{tabular}{|c|c|c|c|c|c|c|}
\hline \multirow{2}{*}{ Strategies /item (Chinese) No. } & \multicolumn{5}{|c|}{ Letters' No. } & \multirow{2}{*}{$\begin{array}{l}\text { Total } \\
\text { Times }\end{array}$} \\
\hline & $\begin{array}{l}\text { No } \\
.1\end{array}$ & $\begin{array}{r}\mathrm{N} \\
\text { o. } 2\end{array}$ & o. 3 & $4^{\mathrm{No}}$ & $.5^{\mathrm{No}}$ & \\
\hline IFID & 1 & 1 & 1 & 1 & 1 & 5 \\
\hline Taking on Responsibility & 1 & 1 & 1 & 0 & 0 & 3 \\
\hline Promise of Forbearance & 1 & 0 & 0 & 0 & 0 & 1 \\
\hline Offer of Repair & 1 & 0 & 0 & 1 & 0 & 2 \\
\hline Statement of Apology fact & 1 & 1 & 0 & 1 & 1 & 4 \\
\hline Explanation or Account & 1 & 1 & 1 & 0 & 1 & 4 \\
\hline Concern for the Hearer & 0 & 0 & 0 & 0 & 0 & 0 \\
\hline Refusal to Acknowledge Guilt & 0 & 0 & 0 & 0 & 0 & 0 \\
\hline Expression of Gratitude & 1 & 1 & 0 & 0 & 0 & 2 \\
\hline $\begin{array}{l}\text { Put Forward to Wish or } \\
\text { Demand }\end{array}$ & 1 & 1 & 0 & 0 & 0 & 2 \\
\hline Total Strategies & 8 & 6 & 3 & 3 & 3 & 23 \\
\hline
\end{tabular}

Table 2 Numbers of the apology strategies used by the public figures in the open letters of English.

\begin{tabular}{|c|c|c|c|c|c|c|}
\hline \multirow[t]{2}{*}{ Strategies /item (Chinese) No. } & \multicolumn{5}{|c|}{ Letters' No. } & \multirow{2}{*}{$\begin{array}{l}\text { Total } \\
\text { Times }\end{array}$} \\
\hline & $\begin{array}{l}\text { No } \\
.1\end{array}$ & $\begin{array}{r}\mathrm{N} \\
\text { o. } 2\end{array}$ & o. 3 & $4^{\text {No }}$ & $5^{\text {No }}$ & \\
\hline IFID & 1 & 1 & 1 & 1 & 1 & 5 \\
\hline Taking on Responsibility & 1 & 1 & 1 & 1 & 1 & 5 \\
\hline Promise of Forbearance & 1 & 0 & 0 & 0 & 0 & 1 \\
\hline Offer of Repair & 0 & 0 & 0 & 0 & 0 & 0 \\
\hline Statement of Apology fact & 0 & 1 & 1 & 0 & 1 & 3 \\
\hline Explanation or Account & 0 & 0 & 0 & 1 & 1 & 2 \\
\hline Concern for the Hearer & 0 & 0 & 0 & 0 & 1 & 1 \\
\hline Refusal to Acknowledge Guilt & 0 & 0 & 0 & 0 & 0 & 0 \\
\hline Expression of Gratitude & 0 & 0 & 0 & 1 & 0 & 1 \\
\hline $\begin{array}{l}\text { Put Forward to Wish or } \\
\text { Demand }\end{array}$ & 0 & 1 & 0 & 1 & 0 & 2 \\
\hline Total Strategies & 3 & 4 & 3 & 5 & 5 & 20 \\
\hline
\end{tabular}

The apology strategies used by the public people in the open letters of Chinese and English were compared to identify potential similarities and differences in the popular media.

The public figures $(100 \%)$ used the IFID, which avoids the further anger and hostility and save the victim's face with effectiveness.

The strategy of Explanation or Account is also employed frequently, because this strategy can reduce the victim's discontent, but also can absolve of responsibility for him/her. The explanation or account strategy is always preferred by the public figures, because the offender gives more information which the victim and the public wanted and it also makes the offender win sympathy and understanding, so it is often employ by the public figures in the popular media.

The strategy of Concern for the hearer did not often appeared. The reason is that the offender faced the popular media rather than the victim, so this strategy seldom appeared in the open letter.

The two strategies of the Expression of Gratitude and Put Forward to Wish or Demand are often employed, which is a special feature in the open letter. The public figures not only hurt the victims, but also have a negative effect on the mass; therefore, the public figures need to express the gratitude toward the mass who understand and support them. On the other hand, the victim was 
forced to be a focus of this matter in the society, which makes the victim bear more pressure from the society. Therefore, the public figure wishes the mass to forget this wrong behavior. This is an effective way to reestablish a public image.

Language reveals a culture's basic value structure[9]. The differences of East and West Culture must contribute to the differences of apology strategies adopted by people.

Firstly, it should be noted here that although apology strategies are presented individually, a combination of two or more strategies were often used by the respondents, which may be partly attributed to their attempt to aptly express remorse. The maximum numbers of combination of the apology strategies employed by Chinese public figures is 8 whereas 5 of that used by western public figures. Totally, 23 strategies in 5 Chinese letters are three more than those in 5 English letters.

Secondly, there are some differences in the frequency of each strategy that is used between the Chinese public figures and English public figures. Nine apology strategies (zip., IFID, Taking on Responsibility, Promise of Forbearance, Concern for the hearer, Offer of Repair, Explanation or Account, Statement of apology fact, Expression of gratitude, Put forward to wish or demand) are adopted by Chinese and English except one strategy (namely Refusal to acknowledge guilt). The strategies of the Explanation or Account, and Statement of apology fact are more used in Chinese than those in English. On the other hand, the strategies of the Taking on Responsibility are more employed in English than that in Chinese.

Therefore, the contrasts of these apology strategies between Chinese and English express their fundamentally different approaches to the East-West cultural values. Westerners concentrate more on culpability and Easterners on consequences. Whereas an American would look for the person at fault in a certain incident, a Chinese, for example, would examine the results of the incident. Yet, both cultures look for ways to save face and, thus, end up blaming each other [10].

\section{Summary}

This study has investigated the differences in the realization patterns of apology among westerner and Chinese in the popular media, at the same time, has pointed out the special features in the open apology letter presented by the public figures. The differences in the use of apology strategies caused not only by the western and eastern culture but also by the social distance and ranking of imposition between offender and victim.

It is worth noting that this research only focuses on the use of apologies strategies by the offender in the public occasion. The victim's potential reaction to this apology is beyond the scope of the study although it is a potential area for further investigation in future research.

\section{References}

[1] E. Olshtain, Apologies across cultures: In: Blum-Kulka, Shoshana, House, Juliane, Kasper, Gabriele (Eds.), Cross-Cultural Pragmatics: Requests and Apologies. Ablex, Norwood, New Jersey 1989.

[2] H. Gooder, Jacobs and M. Jane: On the Border of the Unsayable: the Apology in Postcolonizing Australia. Interventions, Vol 2 (2000) No. 2, pp. 229-247.

[3] B. Fraser, On Apologizing. In: Coulmas, Florian (Ed.), Conversational Routine: Exploration in Standardized Communication Situations and Prepatterned Speech. Mouton de Gruyter, The Hague 1981.

[4] E. Olshtain, Cohen and D. Andrew, Apology: A Speech Act Set. In: Wolfson, Nessa, Judd, Elliot (Eds.), Sociolinguistics and Language Acquisition. Newbury House, Rowley, Massachusetts 1983, pp. 18-35.

[5] J. Holmes, Apologies in New Zealand English. Language in Society, Vol 19 (1990) No.2, pp. $155-199$.

[6] F. Al-Hami, Forms of Apology used by Jordanian Speakers of EFL: A Cross-cultural Study. Unpublished Master's Thesis University of Jordan, Amman, Jordan 1993. 
[7] A. Trosborg, Apology Strategies in Natives/Non-natives. Journal of pragmatics, Vol 11(1987) No.2, pp.147-167.

[8] A. Trosborg, Interlanguage pragmatics: requests, complaints, and apologies. Mouton de Gruyter, Berlin 1995.

[9] E. Zhang. Intercultural Communication. Foreign Language Teaching and Research Press, Beijing 2018.

[10] P. Gries and K. Peng, (2002). Culture clash? Apologies east and west. Journal of Contemporary China, Vol 11 (2002) No. 30, pp. 173-178. 